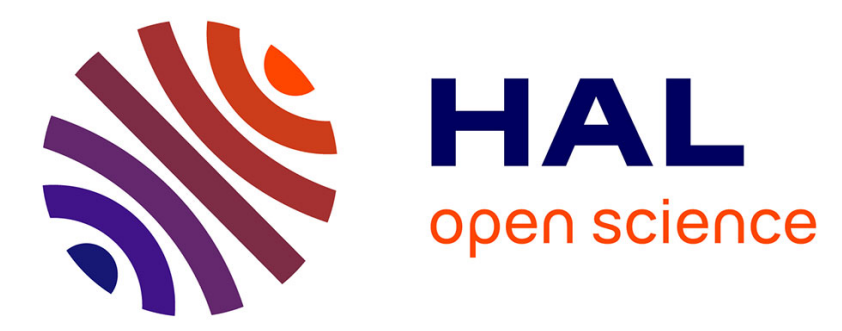

\title{
Primary and secondary Raynaud's phenomenon: does small neuropathy remain the same?
}

Gianluigi Bajocchi, Rossana Terlizzi, Ilaria Chiarolanza, Pietro Cortelli

\section{To cite this version:}

Gianluigi Bajocchi, Rossana Terlizzi, Ilaria Chiarolanza, Pietro Cortelli. Primary and secondary Raynaud's phenomenon: does small neuropathy remain the same? Rheumatology International, 2010, 31 (7), pp.977-978. 10.1007/s00296-010-1491-5 . hal-00615348

\section{HAL Id: hal-00615348 \\ https://hal.science/hal-00615348}

Submitted on 19 Aug 2011

HAL is a multi-disciplinary open access archive for the deposit and dissemination of scientific research documents, whether they are published or not. The documents may come from teaching and research institutions in France or abroad, or from public or private research centers.
L'archive ouverte pluridisciplinaire HAL, est destinée au dépôt et à la diffusion de documents scientifiques de niveau recherche, publiés ou non, émanant des établissements d'enseignement et de recherche français ou étrangers, des laboratoires publics ou privés. 
Primary and secondary Raynaud's phenomenon: does small-neuropathy remain the same?

\section{Dear Sir,}

We took great interest in reading Manek and Coll paper's [1], who hypothesize the presence of a small-fiber neuropathy in primary Raynaud's phenomenon (RP). Indeed, we reached similar results testing 12 patients with secondary RP in systemic sclerosis (SSc) when compared to a group of healthy controls [2]. In these patients, cardiovascular reflexes tested by tilt-test, Valsalva manoeuver, deep breathing and sustained handgrip were normal but the cold face test was abnormal in almost all patients. By this test we explored the function of afferent cutaneous $C$ and $A \delta$ fibres instead of using the cold pressor test, which is painful and is difficult to perform in SSc patients with severe sclerodactyly. In healthy people a cold stimulus applied to the face during spontaneous breathing evokes bradycardia and peripheral vasoconstriction as measured by increased systolic and diastolic blood pressure [3]. Our SSc patients with secondary RP showed blunted bardycardic and hypertensive response to cold-face test, suggesting that a dysfunction of epidermal small fibers (C-fibers) may be involved in SSc.

Manek observations as well as ours are very preliminary and the number of patients is too low to definitely prove a unique and characteristic small-fiber neuropathy in the RP. However, assuming there is a small-fiber neuropathy in both primary and secondary RP, the question arises as to whether the same fibers are involved or to the same extent in both conditions. There are several observations supporting the idea that this may not be the case.

Autonomic c-fibers around sweet glands are deep, mostly located between dermis and subcutaneous tissue. Skin biopsy in SSc with secondary RP showed loss of sensory 
neuropeptidic fibers sprouting from dermal papillary layer into the epidermis, whereas a similar picture but with less severe loss of fibers was described in primary $\operatorname{RP}[4,5]$. Peripheral neuropathy is intriguingly common evidence of very different diseases such erythromelalgia [6], connective tissue diseases $[2,5,7,8]$, and $\mathrm{RP}[1,2,4,5,9]$. It seems unlikely that the same postganglionic neuropathy is involved in all these conditions, unless the small fiber neuropathy is considered as a sign of neuropeptidic dysfunction that may manifest in different pathophysiologic ways thereby leading to a different clinical presentation.

Further studies are needed to clarify this issue although the number of converging results not due to chance is increasing, possibly opening up new avenues of therapies for these diseases. 
References:

1) Manek NJ, Holmgren AR, Sandroni P, Osborn TG, Davis MD. (2009) Rheumatol Int Dec 25. [Epub ahead of print]

2) Bajocchi G, Terlizzi R, Zanigni S, Barletta G, Grimaldi D, Pierangeli G, Cortelli P. (2009) Evidence of a selective nociceptive impairment in systemic sclerosis Clin Exp Rheumatol May-Jun;27(3 Suppl 54):9-14

3) Mathias CJ, Bannister R: Investigation of autonomic disorders In: R Bannister (Ed). Autonomic failure. A textbook of clinical disorders of the autonomic nervous system. Oxford: Oxford University Press 1992;p.255-290

4) Bunker CB, Terenghi G, Springall DR, Polak JM, Dowd PM (1990) Deficiency of calcitonin gene-related peptide in Raynaud's phenomenon Lancet 336:1530-3

5) Terenghi G, Bunker CB, Liu YF et al (1991) Image analysis quantification of peptidemmunoreactive nerves in the skin of patients with Raynaud's phenomenon and sistemic sclerosis J Pathol; 164: 245-52.

6) Davis MD, Sandroni P, Rooke TW, Low PA (2003) Erythromelalgia: vasculopathy, neuropathy, or both? A prospective study of vascular and neurophysiologic studies in erythromelalgia. Arch Dermatol 139(10):1337-1343

7) Omdal R, Mellgren SI, Goransson L, Skjesol A, Lindal S, Koldingsnes W et al (2002) Small nerve Fiber involvement in sistemic lupus erythematosus: a controlled study. Arthritis Rheum 46(5):1228-1232

8) V Provitera, M Nolano, N Pappone, C di Girolamo, A Stancanelli, F Lullo, C Crisci, L (2005) Distal degeneration of sensory and autonomic cutaneous nerve fibres in systemic sclerosis. Ann Rheum Dis Oct;64(10):1524-6

9) Mondelli M, Romano C, De Stefano R, Cioni R (2000) Nerve conduction velocity study of the upper limb in Raynaud's phenomenon. Rheumatol Int 19(5):165-169 